\title{
Effect of seed soaking on seed germination and growth of bitter gourd cultivars
}

\author{
Ehtesham Jamil*, Shah Zeb, Qazi Shoaib Ali, Naveed Ahmad, \\ Muhammad Sajid, Sajid Siddique and Muhammad Saeed Saleem \\ Department of Horticulture, The University of Agriculture, Peshawar, Pakistan. \\ *Corresponding author's email: ehteshamhort@yahoo.com \\ Citation \\ Ehtesham Jamil, Shah Zeb, Qazi Shoaib Ali, Naveed Ahmad, Muhammad Sajid, Sajid Siddique and Muhammad \\ Saeed Saleem. Effect of Seed Soaking on Seed Germination and Growth of Bitter Gourd Cultivars. Pure and \\ Applied Biology. Vol. 5, Issue 1, 2016, pp31-36. http://dx.doi.org/10.19045/bspab.2016.50005
}

Received: 04/05/2015

Revised: 10/12/2015

Accepted: $12 / 12 / 2015$

Online First: 18/12/2015

\section{Abstract}

Present experiment was performed to investigate the possible role of seed soaking in improving seed germination, growth and yield along with good bitter gourd (Momordica charantia L.) cultivar in district Bhimber. In present experiment three bitter gourd (Momordica charantia L.) cultivars i.e. Faisalabad Long, Jaunpuri and Palee were used along with soaking durations $(0,4$, 8,12 and 16 hours). Results revealed that cultivars and soaking durations have significant effect on growth and yield. Among cultivars, cultivar Palee was more effective in enhancing germination percentage (85.56\%), earlier emergence (6.28), fruits plant ${ }^{-1}$ (21.09) and yield (23.94 tones). Seed soaking for 12 hours improved germination percentage $(85.18 \%)$, fruits plant $^{-1}$ (20.70) and yield (19.13 tones) of bitter gourd cultivars. Seed soaked for 16 hours minimized the number of days to emergence (6.28). In crux, seed soaking of cultivar Palee in water for 12 hours has the potential to improve germination, seedling growth and yield and may be recommended for best results regarding maximum germination, growth and yield under the agroclimatic condition of district Bhimber, Azad Kashmir Pakistan.

Key words: Bitter gourd; Cultivars; Soaking durations; Germination; Growth; Yield

\section{Introduction}

Field emergence and poor seedling establishment is always a problem in crops even with the seeds as the embryo is enclosed by a thick seed coat, which affects the germination by imposing mechanical restriction on embryo growth. To overcome this problem, pre-sowing treatments soaking or priming of seeds can be practiced. Presowing technique involves seed hydration up to the point of radical protrusion. Germination and seedling establishment are critical stages in the plant life cycle. In crop production, stand establishment determines plant density, uniformity and management options [1]. Pre-germinated seeds proved superior in emergence from the soil and in stand establishment. The additional advantages of this treatment include, (i) lower seed rate, (ii) dead seeds can be discarded before sowing, and (iii) germinating, but low vigor seeds can be removed before sowing. Recent studies on a series of crop species demonstrate speedy 
germination, early emergence, and vigorous seedlings accomplished by seed pre-soaking which may lead to higher crop yield [2]. This practice of soaking is expressed that on-farm seed priming is a simple, inexpensive, and less risk process of improving faster seedling establishment and vigorous early crop growth. Pre-sowing seed treatments resulted in higher germination and earlier seedling emergence, strong growth, early flowering, maturity and high yields. Speedily germinating seedlings also produce deep root system and improved seedling establishment in many crops. Bitter gourd or balsam pear (Momordica charantia L.) is one of the most popular cucurbitaceous vegetables which find its prime place among the high valuable vegetables, because of its nutritive value and medicinal properties. It is one of the most important summer vegetable crop in Pakistan. It is a widespread vegetable grown in Asia and other part of the world. Optimum temperature of $25-28{ }^{0} \mathrm{C}$ is required for the germination of bitter gourd seeds [3]. Bitter gourd has tremendous economic and dietic importance. Immature fruit is a good source of Vitamin C, and also contains Vitamin A. Bitter gourd is a blood purifier, activates spleen and liver and is highly beneficial in diabetes [4]. The embryo of bitter gourd seeds is enclosed by a thick seed coat, which affect the germination and causes poor field emergence and seedling establishment. Therefore, seed soaking is a useful to bitter gourd growers under sub-optimal temperature condition for definite successful seedling establishment $[5,6]$. Thus the objectives of this study were to investigate the effect of seed soaking on the growth and yield of bitter gourd and to find out the high yielding and better-adopted bitter gourd cultivar under the agro climatic conditions of district Bhimber, Azad Kashmir.

\section{Experimental Details and Treatments Experimental material}

Experiment was performed at Vegetable Research Farm Singri, Bhimber Azad Kashmir, during March, 2012. The experiment was laid out in Randomized Complete Block Design (RCBD) with two factor factorial having 15 treatments and each treatment was replicated 3 times. The plot size was kept $1.5 \mathrm{~m}$ x $2 \mathrm{~m}\left(4.5 \mathrm{~m}^{2}\right)$. Plants were grown on one side of the ridges. Row to row and plant to plant distance was kept $1.5 \mathrm{~m}$ and $60 \mathrm{~cm}$ respectively. All the treated seeds of bitter gourd cultivars were sown at $60 \mathrm{~cm}$ apart on the ridges. Two to three seeds were sown at a gentle depth of 2 to $2.5 \mathrm{~cm}$. Soil was pressed roughly around the seeds. After seedlings emergence thinning was performed to keep one plant hole ${ }^{-1}$.

\section{Treatments}

Three cultivars of bitter gourd i.e. Faisalabad Long, Jaunpuri and Palee were soaked in water for various soaking durations (4, 8, 12 and 16 hours) along with control to determine the optimal soaking duration and find out the best yielding cultivar. Data on Germination percentage, Number of days to emergence, Number of days to first flowering, Fruit plant ${ }^{-1}$ and Yield ha ${ }^{-1}$ was recorded.

\section{Statistical analyses}

The recorded data on different parameters were analyzed by using the statistical computer soft ware, MSTATC (Michigan State University, USA). An analysis of varience (ANOVA) and LSD test was performed to find out the difference between treatments and interaction. The mean values for difference were compared by using Least Significant Difference test.

\section{Results}

\section{Germination percentage}

The bitter gourd cultivars showed a significant $\quad(\mathrm{P}<0.05) \quad$ variation for germination percentage. Regarding mean values of experimental results, the highest 
germination percentage $(85.56 \%)$ was recorded in cultivar Palee followed by cultivar Faisalabad long (78.89\%), whereas the lowest germination percentage $(65.57 \%)$ was observed in cultivar Jaunpuri (Table 1). Mean values for soaking duration indicated that the maximum germination percentage
$(85.18 \%)$ was recorded in plants in which seeds were soaked for 12 hours. However, it was at par with the germination percentage $(81.48 \%)$ of plants, soaked for 16 hours. Whereas the minimum germination percentage $(70.38 \%)$ was observed in plants in which seeds were non soaked (Table 1).

Table 1. Germination percentage as affected by seed soaking of bitter gourd cultivars.

\begin{tabular}{ccccc}
\hline \multirow{2}{*}{$\begin{array}{c}\text { Soaking duration } \\
\text { (hours) }\end{array}$} & \multicolumn{4}{c}{ Cultivars } \\
\cline { 2 - 5 } & Faisalabad Long & Jaunpuri & Palee & Mean \\
\hline 0 & 72.24 & 61.13 & 77.78 & $70.38 \mathrm{~b}$ \\
4 & 72.24 & 61.13 & 83.34 & $72.24 \mathrm{~b}$ \\
8 & 77.78 & 61.13 & 83.34 & $74.08 \mathrm{~b}$ \\
12 & 88.88 & 72.23 & 94.44 & $85.18 \mathrm{a}$ \\
16 & 83.33 & 72.24 & 88.88 & $81.48 \mathrm{a}$ \\
\hline Mean & $78.89 \mathrm{~b}$ & $65.57 \mathrm{c}$ & $85.56 \mathrm{a}$ & \\
\hline
\end{tabular}

LSD value at $5 \%$ for cultivars $=4.710$

LSD value at $5 \%$ for soaking durations $=6.080$

Values sharing same letters differ non-significantly $(\mathrm{P}>0.05)$

\section{Number of days to emergence}

The bitter gourd cultivars showed a significant $(\mathrm{P}<0.05)$ variation for number of days to emergence. The mean indicated that cultivar Jaunpuri took more days to emergence (7.57) than cultivar Palee (6.47) and Faisalabad Long (6.37).

According to mean values the highest numbers of days to emergence (7.45) were recorded in plants having non-soaked seed, closely followed by plants took 7.36 days to emergence in which seeds were soaked for 4 hours. However, the less number of days to emergence (6.28) were found in plants, soaked for 16 hours (Table 2).

The interaction of bitter gourd cultivars and soaking duration $(\mathrm{P}<0.05)$ showed the maximum numbers of days to emergence (8.00) were noted in cultivar Jaunpuri in non-soaked seeds however, the minimum number of days to emergence (5.77) were recorded in cultivar Faisalabad Long in which seeds were soaked for 16 hours (Table 2).

Table 2. Number of days to emergence as affected by seed soaking of bitter gourd cultivars.

\begin{tabular}{ccccc}
\hline \multirow{2}{*}{$\begin{array}{c}\text { Soaking duration } \\
\text { (hours) }\end{array}$} & Faisalabad Long & Jaunpuri & Palee & Mean \\
\cline { 2 - 5 } & 7.15 & 8.00 & 7.20 & $7.45 \mathrm{a}$ \\
4 & 6.92 & 7.96 & 7.20 & $7.36 \mathrm{a}$ \\
8 & 6.16 & 7.50 & 6.17 & $6.61 \mathrm{~b}$ \\
12 & 5.88 & 7.23 & 5.90 & $6.34 \mathrm{bc}$ \\
16 & 5.77 & 7.16 & 5.90 & $6.28 \mathrm{~b}$ \\
\hline Mean & $6.37 \mathrm{~b}$ & $7.57 \mathrm{a}$ & $6.47 \mathrm{~b}$ & \\
\hline LSD value at 5\% for cultivars & $=$ & 0.2244 & \\
LSD value at 5\% for soaking durations $=$ & 0.2897 & \\
LSD value at 5\% for interaction & $=$ & 0.1296 &
\end{tabular}




\section{Numbers of fruits plant ${ }^{-1}$}

Cultivars showed a significant $(\mathrm{P}<0.05)$ difference for the numbers of fruits plant ${ }^{-1}$. Palee produced higher number of fruits plant $^{-1}$ (21.09), while cultivar Jaunpuri produced less number of fruit plant ${ }^{-1}$ (14.52).

Soaking durations also showed a significant $(\mathrm{P}<0.05)$ difference for the numbers of fruits plant $^{-1}$. Mean values for soaking duration indicated that the highest numbers of fruits plant $^{-1}$ (20.70) were produced, when seeds were soaked for 12 hours, while the less numbers of fruit plant ${ }^{-1}$ (16.68) were recorded in plants of non-soaked seed (Table $3)$.

The interaction of bitter gourd cultivars and soaking duration revealed that the more numbers of fruits plant $^{-1}$ (23.0) were observed in cultivar Palee in which seeds were soaked for12 hours. While less numbers of fruits plant $^{-1}$ (12.10) were produced by cultivar Jaunpuri of unprimed seeds (Table 3).

Table 3. Number of fruits plant ${ }^{-1}$ as affected by seed soaking of bitter gourd cultivars.

Soaking duration

(hours
(hours)

\begin{tabular}{lcc}
0 & 17.36 & 12.10 \\
4 & 18.96 & 13.20 \\
8 & 20.33 & 14.73 \\
12 & 21.46 & 17.63 \\
16 & 19.63 & 14.96 \\
Mean & $19.53 \mathrm{~b}$ & \multicolumn{2}{c}{$14.52 \mathrm{c}$} \\
$\%$ for cultivars & \multicolumn{2}{c}{0.8018} \\
$\%$ for soaking durations & $=$ & 1.035 \\
$\%$ for interaction & $=$ & 0.4629
\end{tabular}

$\begin{array}{lll}\text { LSD value at } 5 \% \text { for cultivars } & & = \\ \text { LSD value at } 5 \% \text { for soaking durations } & = & 1.035\end{array}$

$\begin{array}{ll}\text { LSD value at } 5 \% \text { for interaction } \quad= & 0.4629 \\ \text { Values sharing same letters differ non-significantly }(\mathrm{P}>0.05)\end{array}$

Total yield ha-1 (tones)

Cultivars showed a significant $(\mathrm{P}<0.05)$ difference for the yield ha- ${ }^{-1}$. Higher yield ha1 (23.94 tons) was obtained by cultivar Palee, while the lower yield ha ${ }^{-1}$ ( 7.67 tons) was produced by cultivar Jaunpuri (Table 4). Soaking duration significantly $(\mathrm{P}<0.05)$ influenced the yield ha $\mathrm{a}^{-1}$. Regarding to mean Table 4. Yield ha-1 (tones) as affected by seed soaking of bitter gourd cultivars.

\begin{tabular}{ccccc}
\hline $\begin{array}{c}\text { Soaking duration } \\
\text { (hours) }\end{array}$ & Faisalabad Long & Jaunpuri & Palee & Mean \\
\cline { 2 - 5 } & 11.31 & 4.88 & 18.85 & $11.68 \mathrm{~b}$ \\
4 & 13.11 & 5.79 & 21.75 & $13.55 \mathrm{ab}$ \\
8 & 18.10 & 6.69 & 23.80 & $16.20 \mathrm{ab}$ \\
12 & 18.29 & 10.78 & 28.31 & $19.13 \mathrm{a}$ \\
16 & 13.78 & 10.21 & 26.99 & $17.00 \mathrm{ab}$ \\
\hline Mean & $14.92 \mathrm{~b}$ & $7.67 \mathrm{c}$ & $23.94 \mathrm{a}$ \\
\hline LSD value at 5\% for cultivars $=4.710$ \\
LSD value at 5\% for soaking durations $=6.080$ \\
Values sharing same letters differ non-significantly $(\mathrm{P}>0.05)$
\end{tabular}

${ }^{1}(19.13$ tons $)$ was recorded where seeds were soaked for 12 hours, followed by (17.00 tons) yield ha ${ }^{-1}$ when seeds were soaked for 16 hours. The lowest yield $\mathrm{ha}^{-1}$ (11.68 tons) was obtained in unsoaked seed (Table 4). 


\section{Discussion}

Pre-soaking of seed resulted in higher germination and earlier seedling emergence and high yields. Speedily germinating seedlings produced deep root system which resulted strong seedling establishment in the crop. Significant improvement in germination were observed by the fact that soaking stimulates series of biochemical change in the seed that are essential to initiate the emergence process like break down dormancy, hydrolysis, metabolism of growth inhibitors, imbibitions, activation of enzymes. Seed soaking significantly minimized the emergence time Soaking stimulates and produces enzymes like amylase and lipase which activate storage materials in seeds. Rehydration causes early emergence due to the fact that all pregerminative processes for germination had already occurred in seed. [7-9]. The probable reason for increased germination through soaking duration may be that each species requires an optimum amount of water to enter in lag phase of germination. All the pre-germinative processes take place in this phase $[10,11]$. In this, study results showed that cultivars significantly improve germination and earlier emergence these variations among the bitter gourd cultivars might be due to genetic potential.

Pre-soaking of seed encourage growth of crop, reduced days to emergence, numbers of branches plant ${ }^{-1}$ and plant yield [12]. More numbers of fruits were obtained because the earlier emergence and better crop establishment lead to healthy and more branches which ultimately resulted in higher numbers of fruits plant ${ }^{-1}$ [2]. Cultivar Palee produced more number of fruit than other two cultivars which is due to its genetic potential. The numbers of fruits plant ${ }^{-1}$ is a key component for final yield. Many factors involved which affect the crop yield. Results indicates that higher yield which was obtained due to the overall effect of pre- soaking on germination, better and strong emergence and uniform seedling growth which is a key step in later plant growth and yield [13-15]. In conclusion, although with substantial varietal difference, different soaking durations has the potential to enhance germination and seedling growth. Seed soaking for 12 hours effectively enhanced emergence, seedling vigor, crop establishment of the bitter gourd cultivar. Further studies are needed to find the possible mechanism(s) of the growth improvement.

\section{Authors' contributions}

Conceived and designed the experiments: $\mathrm{M}$ Sajid. Performed the experiments: E Jamil, MS saleem \& QS Ali. Analyzed the data: S Zeb, N Ahmad \& QS Ali. Contributed reagents/ materials/ analysis tools: $\mathrm{S}$ Siddique, MS Saleem \& E Jamil. Wrote the paper: S Zeb \& S Siddique.

\section{References}

1. Cheng Z \& Bradford KJ (1999). Hydrothermal time analysis of tomato seed germination responses to priming treatments. J. Exp. Bot. 330: 89-99.

2. Harris D, Tripathi RS \& Joshi A (2000). On-farm seed priming to improve crop establishment and yield in dry directseeded rice. Paper presented at the workshop on dry seeded rice Technology, Bangkok, Thailand.

3. Peter KV, Sadhu MK, Raj M \& Prasanna KP (1998). Improvement and cultivation of bitter gourd, snake gourd, pointed gourd and ivy gourd. In: Nayar, N. M., More, A. (Eds.), Cucurbits. Sci. Publishers Inc., Enfield, NH, USA, 187195.

4. Yibchok AS, Adisakwattana S, Yao CY, Sangvanich P, Roengsumran S \& Hsu WH (2006). Slow acting protein extract from fruit pulp of Momordica charantia with insulin mimetic activities. Biol. Pharm. Bull. 29: 1126-1131. 
5. Wang HY, Chen CL \& Sung JM (2002). Both warm water soaking and solid priming treatments enhance antioxidation of bitter gourd seeds germinated at sub-optimal temperature. Seed Sci. Technol. 31: 47-56.

6. Lin JM \& Sung JM (2001). Pre-sowing treatments for improving emergence of bitter gourd seedlings under optimal and sub-optimal temperatures. Seed Sci. Technol. 29: 39-50.

7. Ajouri A, Asgedom S \& Becker M (2004). Seed priming enhances germination and seedling growth of barley under conditions of $\mathrm{P}$ and $\mathrm{Zn}$ deficiency. J. Pl. Nutri. Soil Sci. 16(2): 630-636.

8. Farooq M, Basra SMA, Khaliq A \& obayashi NK (2009). Rice seed invigoration. Biomedical \& Life Sci. 1: 137-175.

9. Pukacka S \& Ratajczak E (2005). Production and scavenging of reactive oxygen species in Fagus sylvatica seeds during storage at varied temperature and humidity. J. Plant Physiol. 162: 873-885.

10. Sadeghi, Khazaei F, Yari L \& Saman germination behaviour of soybean
(Glycine max L.) ARPN J. Agric. and Biol. Sci. 6: 39-43.

11. Pazdera J \& Hosnedl V (2002). Effect of hydration treatments on seeds parameters of different lettuce (Lactusa sativa L.) seed lots. Hort. Sci. 29: 12-16.

12. Ullah M, Sarfraz AM, Sadiq M, Mehdi SM \& Hassan G (2002). Effect of presowing seed treatment with micro nutrients on growth parameters of raya. Asian J. Pl. Sci. 1: 22-23.

13. Zhang M, Nyborg M \& McGill WB (1998). Phosphorus imbibed by barley seed, location within the seeds and assimilation by seedlings. Seeds Sci. Tech. 26: 325-332.

14. Harris D, Raghuwanshi BS, Ganwar JS, Sing SC, Joshi KD, Rashid A \& Hollington PA (2001). Participatory evolution by farmers of on form seed priming in wheat in India, Nepal and Pakistan. Exp. Agric. 37: 403-415.

15. Kaur S, Gupta AK \& Kaur N (2005). Seed priming increases crop yield properly by modulating enzymes of sucrose metabolism in chickpea. J. Agro \& Crop Sci. 191: 81-87. 